\title{
TOMMY DOWER AND THE PERTH NEWSPAPERS
}

\author{
G.C. Bolton
}

Among the pioneer graves in the East Perth cemetery is a well-kept headstone commemorating Tommy Dower, who died on 2 July 1895 at the age of fifty. According to his epitaph: 'He was possessed of more than ordinary intelligence and ability'. He is almost certainly the only person of Aboriginal origin interred among Perth's colonial élite. It is usually thought that he owes this distinction to being the survivor of the three notable Aborigines- all of them called Tommy - who accompanied the Forrest brothers on their expeditions in the 1870 s. Tommy Windich, a Koker ${ }^{1}$ from the Kellerberrin district taken when young to the Forrests' district of Bunbury, went on the 1870 and 1874 transcontinental expeditions, and was buried at Esperance when he died in 1876 in his midthirties. Tommy Pierre, born about 1836 in the Bunbury district, was on the 1874 expedition and accompanied Alexander Forrest in his 1879 journey across the Kimberleys: he suffered severe illness during its later stages and died at Albany on the way home. ${ }^{2}$ Tommy Dower was the other Aboriginal in Alexander Forrest's eight-man party in 1879; he also accompanied John Forrest in 1881 on the survey of the country between Beverley and Albany which led to the construction of the Great Southern railway. ${ }^{3}$ He survived, and his later history throws up some interesting questions on race relations in the Perth of the 1880 s and 1890 s.

It has been conjectured that Dower's family origins were among the Murray River people who fought and lost the battle of Pinjarra in October $1834 .{ }^{4}$ Dower was born a few years later, some time between 1835 and 1845. I know nothing of his life until he went on Alexander Forrest's expedition in 1879 , but by that time he was a good shot, a useful horseman, and a mature and impressive personality. It would be interesting to speculate how far Forrest's unmolested crossing of the Kimberleys was due to advice from Pierre and Dower about avoiding campsites where the party would be unwelcome to the local Aborigines, and in otherwise exercising their diplomatic skills.

By the time he accompanied John Forrest on the 1881 survey the media were beginning

Geoffrey Bolton is an historian of Australia with wide interests, publishing research on the early settlement of North Queensland and of Western Australia. In the latter field he wrote a biography of Alexander Forrest, thus meeting Tommy Dower. He has held the Chair of Australian Studies at London, and recently moved from the Chair of History at Murdoch University to that at Queenaland. He is the General Editor of the Oxford History of Australia, to which Diane Barwick was to be a major contributor.

1 Oates and Oates (1970:632) give 'Kokar' as one name for the language spoken around Kellerberrin.

2 For Windich and Pierre, F.K. Crowley 1971:30, 65-67; Tommy Windich, ADB vol.6, pp.422-23.

3 Western Australia, Legislative Council, Votes and Proceedings, 1882, No.2.

4 I owe this suggestion to Mr Neville Green, Mt Lawley campus, Western Australian College of Advanced Education. 
to take notice of him. The Albany correspondent of the Perth Inquirer wrote: Tommy, with his drolleries, is quite a host among our youngsters; he is certainly very intelligent, and his knowledge of the English language and conversational powers are quite marvellous. 5 The Inquirer , owned by the old-colonist Stirling family, usually gave the Forrests a good press. With its stablemate the Daily News, founded in 1882, it favoured responsible government and criticised Government House. The conservative viewpoint was represented by the West Australian Times, after 1884 the West Australian, owned by Charles Harper and Winthrop Hackett. Both papers were to find some interesting copy in Tommy Dower.

Alexander Forrest had been rewarded for his Kimberley expedition by a grant of 2000 acres recommended by the Legislative Council. Some of his admirers considered this insufficient, and in 1882 a resolution was passed to increase the grant to 5000 acres. $^{6}$ The Inquirer strongly supported Forrest's claims, but a month or two later there was a sequel:

Thomas Dower, the aboriginal native who accompanied Mr Alexander Forrest on his exploring trip to Port Darwin, wishes to know how it is he has not been remunerated either in money or land, for his services on that occasion. He learns that the other members of Mr Forrest's party have been handsomely treated by the Government. "Thomas" is aware that he has a good claim to a very extensive landed estate in this part of Australia, acquired by hereditary right, but he has not the means at command, just now at least, to press his claims further. He considers, however, that the "laborer is worthy of his hire", and that he is fully entitled to a share of the amount voted by the Legislature.

And we think so too. 7

The tone of this report, veering as it does between the satirical and the humanitarian, must have struck some readers a little uneasily. The Inquirer usually backed the Forrests, but its managing editor, Horace Stirling, was known to sympathise with the Aboriginal viewpoint; some years later Dower is reported as calling him 'a fair talking good man, he take more part of blackman than whiteman. ${ }^{.8}$

From that time onward Dower seems to have realised that he could occasionally command publicity for Aboriginal land claims. His prestige among the white community as a member of the Forrests' exploring parties and a recipient of their patronage was enhanced by his reputation for intelligence and his assumption of a position of leadership among the Perth Aboriginal community. After the death of Winjan, the senior Aboriginal male of the older generation, ${ }^{9}$ and the loss of many lives in the measles epidemic of 1883-84, Dower was regarded as the spokesman for the remnant Aboriginal community. He played up to the readiness of the local press to treat him as an entertaining character, but by doing so managed to gain a hearing for his views more than any other Aboriginal of his time. In 1886 he applied for ten acres at Freshwater Bay (now Claremont) as a freehold reserve for the Aboriginal community. This showed a little audacity, as Claremont was just starting to be opened up as a desirable middle-class suburb halfway between Fremantle and Perth; in earlier years ten acres had been the standard allotment allocated at Freshwater Bay to pensioner guards in charge of convicts. The Inquirer, noting Dower's intention to 'build him

Inquirer, 30 November 1881.

Bolton 1958:38.

7 Inquirer, 22 November 1882.

8 West Australian, 21 March 1893.

9 Hammond 1936. 


\section{TOMMY DOWER}

a house and plant him ground', gave qualified support: 'Provided that Tommy be restricted from selling the grant, it is to be hoped that his application will prove successful'. ${ }^{10}$

Nothing followed, although John Forrest as Surveyor General might have been expected to sympathise. But he was on bad terms with Governor Broome, and might not have been in a position to help. Malcolm Fraser, the Colonial Secretary and himself formerly Surveyor General, would not have been sympathetic. In January 1885 , commenting on Dower's conviction and sentence to one month's imprisonment on a charge of being drunk and disorderly at Fremantle railway station, Fraser minuted: This native used to be a very useful man; has been out with exploring parties and on surveys, but of late he has become a loafer in Perth and Fremantle and a nuisance to those he knows. He always begs from me when we meet. I hope this sentance may be a warning to him'.11 Fraser himself was occasionally suspected of taking a drop too much, but his attitude sufficiently explains official inaction.

In October 1886 the Inquirer ran a letter from an anonymous correspondent signing himself 'Justice', who claimed to have met Dower camped in the bush on the banks of the Swan not far from Perth. Only one old man among the group was drawing government rations, and Dower was reported as saying 'That white man take all blackfellows' country, and that blackfellow no place sit down. That white man build houses, fence land, run cattle, sheep, horse, on blackfellows country. But poor blackfellows, no horse, no kangaroo or emu left. That plenty blackfellow die, and no notice taken of him by white man. ${ }^{12}$

Nothing came of this plea, but during the next few months Dower figured twice in the press. In December 1886 he and other Aborigines were reported as highly critical of the black swans ornamenting the newly erected Fremantle Town Hall; they looked, he said, like a snake emerging from its hole, and he sketched a more likely-looking swan for the mayor of Fremantle. ${ }^{13}$ In May 1887 he was again gaoled for three days for drunkenness, and Mary Oates, publican at the No Place Inn, was charged with supplying him with a bottle of beer. It was stated that having bought the beer for his wife, who was unwell, Dower fell into conversation with two policemen who saw the neck of the bottle protruding from his pocket. They offered to let him off the prison sentence if he informed them where he obtained the beer, but did not let him go. As the case was adjourned for two days and not subsequently reported, the end of the story is unknown. ${ }^{14}$

By 1890 Western Australia had won self-government with John Forrest, soon to be knighted, as its first premier. Mistrustful of colonial attitudes towards the Aborigines, the British government insisted that one percent of the colony's revenue should be devoted to Aboriginal welfare, and provided for an Aborigines Protection Board to oversee the conduct of policy. The Board, although largely ineffectual and composed of elderly citizens without great political weight, was unpopular with most colonial politicians, who were soon campaigning for its abolition. Dower was used - how willingly? - as a voice in favour of its abolition. In March 1893 the West Australian published what purported to be a dictated letter from Dower in his capacity as 'King of West Australia, friend of Mr Sir John Forrest and friend of Mr Alexander Forrest:

10 Inquirer, 29 September 1886.

11 C.S.O. 415/85 (Box 694, Battye Library); memo by Col. Sec. 29 January 1885.

12 Inquirer, 13 October 1886.

13 Inquirer, 8 December 1886.

14 West Australian, 10 May 1887. 
Well now, the people of West Australia don't treat us right, we want fair play, same as other side. In the Port Fremantle, Perth City, and Guildford we must have tent and blanket, same as you, and want 'em now soon, not by and by when rain all gone away.

Natives very few now, and the Government must look after them. You arrive in Fremantle, no natives. When you land in Fremantle, you see all whitefellow and no natives. In two or three year you won't see one whitefellow clear the lot. ${ }^{15}$

He had a low opinion of the Aborigines Protection Board: 'Wangie Wangie once a week and do nothing.' Of its pompous and eccentric chairman, George Walpole Leake, he said: 'He is a bad chairman I think. I never speak to him. I always see him go past, that is all.'16 Six months later, when the motion came before the Legislative Assembly to abolish the Board, Alexander Forrest quoted him in the same strain:

Even the natives themselves object to the Board. I know that my old friend, King Dower, who is the head of the native population in this part of the colony, says he objects strongly to the Board; he says they are not competent to look after the natives, and that he would much rather be under the old form of Government, when he could go and see the head of the Government and get proper treatment. 17 .

Parliament duly recommended the Board's abolition, but it survived until 1897 when Sir John Forrest visited London for Queen Victoria's Diamond Jubilee and persuaded Joseph Chamberlain to comply. With the Board was swept away Western Australia's obligation to spend one per cent of government revenue on the Aboriginal population. Dower did not survive to witness these developments. He had been in poor health for some time, and although he was fit enough to be photographed in ceremonial garb with two others for a Christmas number of the West Australian in 1894, the following winter was too much for him, and he died in his camp on 2 July 1895. His burial in East Perth cemetery and the erection of his tombstone was arranged by the Aborigines Protection Board, no doubt with some prompting from the Forrests, who were at least punctilious in ensuring that their Aboriginal offsiders were given decent funerals.

An ambiguity lingers about the press coverage of Dower's statements. It would be possible to view him as an early spokesman for Aboriginal land rights, who used his prestige and local reputation to voice Aboriginal grievances whenever opportunity offered. It would also be feasible to see him as a pawn in local political squabbles, whose utterances could be used to embarrass the government or the Aborigines Protection Board; or perhaps as Perth's equivalent of a Shakespearian fool, offering shrewd and at times disconcerting comment as priviledged underdog. At the very least, it can be said that he did not go unnoticed.

Idem.

7 Western Australia, Parliamentary Debates, new series, vol.V, p.695. 


\section{TOMMY DOWER}

\section{BIBLIOGRAPHY}

Bolton, G.C. Alexander Forrest. Carlton, 1958.

Crowley, F.K. Forrest. Volume 1, 1847-1891. St Lucia, 1971.

Crowley, F.K. 'Tommy Windich', Australian Dictionary of Biography. Vol.6, pp.422-423.

Hammond, J. Winjan's people. Perth, 1936.

Oates W.J. and Lynette F. Oates. A revised linguistic survey of Australia. Australian Aboriginal Studies No.33. Canberra 1970.

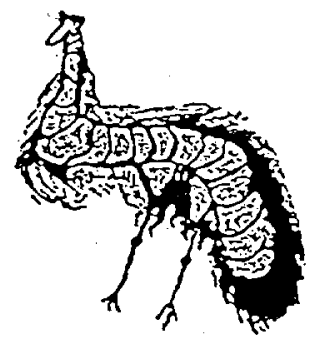

